\title{
KINERJA GURU DAN HUBUNGANNYA DENGAN KUALITAS HASIL BELAJAR SISWA MADRASAH ALIYAH
}

\author{
Asep Habib Idrus Alawi \\ Sekolah Tinggi Agama Islam Shalahuddin Al-Ayyubi Jakarta \\ rianto.msi23@gmail.com
}

\begin{abstract}
The quality of student learning outcomes becomes a barometer of the success of an educational institution, this quality is closely related to the teacher's performance and the principal's leadership style which in this case is known as strategic management, the problem is not yet the teacher's performance in Islamic Senior High School of AlFadilah at 2016/2017 Years teachings until 2017/2018 Year Academic in the learning outcomes of students who take the National Examination are at a minimum score, for that there needs to be a change in teacher performance so that efforts to improve the quality of learning outcomes of Aliyah Al-Fadilah Madrasah can be realized optimally. The author seeks to reveal aspects of weakness and excellence, and efforts to improve the performance of education staff, especially Teacher's performance through clarity of School Vision and Mission with curriculum, application of the Principal's leadership style, Teacher's commitment to professional assignments, Bungbulang school / community background so far, so that it is expected to provide motivation for mastering concepts and applicative teacher performance through the ability or competence they have, so that ultimately the quality of learning outcomes of students of Islamic Senior High School of Al-Fadilah increases.
\end{abstract}

Keywords: Teacher performance, Quality of student learning outcomes 


\section{Abstrak}

Kualitas hasil belajar siswa menjadi sebuah barometer suksesnya sebuah lembaga pendidikan, kualitas ini erat hubungannya dengan kinerja guru dan gaya kepemimpinan kepala sekkolah yang mana dalam hal ini dikenal dengan managemen strategic, permasalahan belum potimalnya kinerja guru di Madrasah Aliyah Al-Fadilah ini terlihat pada periode tahun ajaran 2016/2017 sampai 2017/2018 dimaana hasil belajar siswa yang mengikuti Ujian Nasional berada pada skor minimal, untuk itu perlu adanya perubahan mengenai kinerja guru sehingga upaya-upaya untuk meningkatkan kualitas hasil belajar Madrasah Aliyah Al-Fadilah dapat terwujud secara optimal.penulis berusaha untuk mengungkapkan aspek-aspek kelemahan dan keunggulan, serta upaya untuk meningkatkan kinerja tenaga kependidikan, khususnya kinerja Guru melalui kejelasan Visi dan Misi sekolah dengan kurikulum, penerapan gaya kepemimpinan Kepala Sekolah, komitmen Guru pada tugas profesional, latar belakang sosekbud sekolah/ masyarakat Bungbulang selama ini, sehingga diharapkan memberikan motivasi terhadap penguasaan konsep-konsep dan aplikatif kinerja guru melalui kemampuan atau kompetensinya yang dimiliki, sehingga pada akhirnya kualitas hasil belajar siswa Madrasah Aliyah Al-Fadilah meningkat

Kata kunci : Kinerja guru, Kualitas hasil belajar siswa 


\section{A. Pendahuluan}

Pada dasarnya sekolah sebagai lembaga pendidikan formal bukan hanya sebagai sistem sosial terbuka, agen perubahan (agen of change), namun sebagai tempat untuk menyiapkan peserta didik (siswa) melalui kegiatan bimbingan, pengajaran, dan/atau latihan serta harus peka penyesuaian diri dan dapat mengantisipasi perkembangan-perkembangan yang akan terjadi dalam kurun waktu tertentu. Disni letak pentingnya peran dari Manajemen Stratejik, yaitu pada Visi, Misi, Tujuan, Sasaran, Strategi, Kebijakan, Program, Anggaran, Prosedur, dan Standar Kinerja. Begitu pula memperhatikan input, proses, output, outcomes, benefit (manfaat), dan impact (dampak, pengaruh yang kuat) dari pengaruh gaya kepemimpinan Kepala Sekolah, Visi dan Misi, komitmen guru pada tugas, latar belakang sosial, ekonomi, dan budaya terhadap kinerja Guru dan hubungannya dengan kualitas hasil belajar siswa, khususnya MA Al-Fadilah .

Rendahnya kualitas hasil belajar siswa MA Al-Fadilah pada kurun waktu dua tahun pelajaran terakhir (2016/2017 s.d 2017/2018), dengan hasil rata-rata atau klasifikasi sekolah pada posisi D (rata-rata ujian nasional pada posisi antara 4,50 sampai dengan 5,49), memberi motivasi kepada para Kepala MA AlFadilah untuk meningkatkan kinerja,etos kerja dalam menerapkan gaya kepemimpinannya yang tepat kepada tenaga kependidikan yang ada di sekolah, khususnya kinerja guru, sehingga dapat meningkatkan kualitas hasil belajar siswa dan mutu pendidikan serta mutu sumber daya manusia di Garut.

Tanpa mengurangi arti, kepemimpinan dengan berbagai gayanya dalam membangkitkan sumberdaya manusia, khususnya Guru sebagai pendidik, pengajar, dan pelatih terhadap siswa sangat penting. Oleh karena kepemimpinan pendidikan mempunyai pengaruh substansial terhadap organisasi sekolah, sebagaimana (Lipham,1985,p.2) mengemukakan, bahwa "Kualitas kepemimpinan secara substansial berpengaruh terhadap keberhasilan suatu sekolah". Lebih tegas dikemukakan (Sondang P. Siagian, 1990, p.2), bahwa "Kemampuan yang ada pada manusia itu dapat diarahkan kepada pencapaian tujuan (pendidikan) melalui upaya kepemimpinan".

Dari pernyataan tersebut, sangat berperan untuk mempengaruhi tenaga kependidikan, khususnya guru dalam merencanakan, mengorganisasikan, melaksanakan, mengevaluasi, menganalisis, dan mengadakan pengayaan/ perbaikan 
pembelajaran sebagai kontrol terhadap keberhasilan proses belajar mengajar sesuai dengan tujuan pendidikan yang diharapkan di sekolah itu (tujuan institusional/ lembaga).

Hal ini dapat dilihat dari kenyataan-kenyataan yang ada di MA Al-Fadilah, antara lain :

1. Belum diaplikasikannya secara optimal mengenai kejelasan Visi dan Misi sekolah sebagai landasan kebijakan sekolah dalam jangka waktu tertentu;

2. Masih kurang optimalnya motivasi terhadap tenaga kependidikan, khususnya kinerja guru dalam melaksanakan tugasnya sehari-hari, sehingga berdampak kurang memuaskan (rendah) terhadap kualitas hasil belajar siswa MA Al-Fadilah

3. Belum optimalnya komitmen guru pada tugas profesional di sekolah, yaitu tugas mendidik, mengajar, dan melatih para siswa, sehingga sangat berdampak pada kualitas hasil belajar siswa;

4. Belum menunjangnya keadaan sosial, ekonomi, dan budaya sekolah/ masyarakat Garut terhadap kinerja guru, sehingga berdampak pula terhadap peningkatan kualitas hasil belajar belajar siswa;

5. Belum optimalnya kinerja Guru dalam proses pembelajaran yang mengakibatkan rendahnya kualitas hasil belajar siswa MA Al-Fadilah pada dua tahun pelajaran terakhir (2016/2017 s.d 2017/2018). Oleh karena itu harus ada perubahan (inovasi) mengenai kinerja guru, sehingga upaya-upaya untuk meningkatkan kualitas hasil belajar siswa MA Al-Fadilah dapat terwujud secara optimal.

Dengan adanya fenomena dasar yang dihadapi di MA AlFadilah, penulis berusaha untuk mengungkapkan aspek-aspek kelemahan dan keunggulan, serta upaya untuk meningkatkan kinerja tenaga kependidikan, khususnya kinerja Guru melalui kejelasan Visi dan Misi sekolah dengan kurikulum, penerapan gaya kepemimpinan Kepala Sekolah, komitmen Guru pada tugas profesional, latar belakang sosekbud sekolah/masyarakat Bungbulang selama ini, sehingga diharapkan memberikan motivasi terhadap penguasaan konsep-konsep dan aplikatif kinerja guru melalui kemampuan atau kompetensinya yang dimiliki, sehingga pada akhirnya kualitas hasil belajar siswa MA Al-Fadilah meningkat. 


\section{B. Metode Penelitian}

Metode yang digunakan dalam penelitian ini adalah metode kuantitatif dengan pendekatan Deskriptif Analitis. Deskriptif Analitis terhadap data kuantitatif adalah metode penelitian yang digunakan untuk memberikan gambaran atau mendeskripsikan serta menganalisis hasil-hasil penelitian berdasarkan tafsiran data yang diperoleh melalui angka-angka statistik dengan menekankan kejadian masa kini dan masa lampau.

Penelitian ini dilaksanakan di MA Al-Fadilah yang berlokasi di Kampung Kebon Jambe Desa Wangun Jaya Kecamatan Bungbulang Kabupaten Garut Jawa Barat pada Bulan November 2018

Penelitian ini berfokus pada penelitian komitmen Guru pada tugas, dan budaya terhadap kinerja guru dan hubungannya dengan kualitas hasil belajar siswa MA Al-Fadilah . Oleh karena itu subyek penelitian utama atau responden utama adalah Guru Bungbulang dengan jumlah 40 orang. Dari Guru dan inilah diperoleh data dan informasi mengenai berbagai hal/aktivitas yang ada kaitannya dengan penelitian ini. Rumusan masalah pokok penelitian ini dibatasi dengan masalah-masalah konkret, yang difokuskan lagi ke dalam pertanyaan-pertanyaan penelitian sebagai berikut

1) Seberapa besar pengaruh komitmen guru pada tugas terhadap kinerja guru MA Al-Fadilah ;

2) Seberapa besar kontribusi kinerja guru dalam proses pembelajaran terhadap peningkatan kualitas hasil belajar siswa MA Al-Fadilah .

Masalah pokok dan pertanyaan-pertanyaan penelitian tersebut merupakan acuan penelitian. Oleh karena itu, komitmen guru pada tugas, sangat berpengaruh terhadap kinerja Guru, sehingga dapat dikatakan, bahwa makin tinggi/meningkat kinerja Guru, maka makin tinggi/meningkat kualitas hasil belajar siswa MA Al-Fadilah, bahkan makin meningkat pula kualitas pendidikan dan sumber daya manusia di Kabupaten Garut

Model paradigma penelitian menunjukkan, bahwa adanya pengaruh dari kekedua variabel yang saling berhubungan, baik hubungan timbal balik antar variabel, hubungan secara langsung yaitu variabel Komitmen Guru pada tugas, dan kinerja Guru dan hubungannya dengan kualitas hasil belajar siswa, maupun hubungan tidak langsung pada peningkatan kualitas hasil belajar siswa MA Al-Fadilah. Oleh karena itu dalam penelitian ini 
penulis berkeyakinan, manakala Kinerja Guru senantiasa ditingkatkan, maka kualitas hasil belajar siswa akan meningkat pula. Meskipun demikian, pada tataran pengaruh komitmen Guru pada tugas, dan kinerja Guru dengan kualitas hasi belajar siswa terdapat error (tingkat kesalahan) yang sangat minim

Adapun rumusan hipotesis secara umum dalam penelitian ini untuk diuji kebenarannya, yaitu : "Terdapat pengaruh yang positif dan signifikan mengenai Komitmen Guru pada tugas, kinerja Guru dan hubungannya dengan kualitas hasil belajar siswa MA Al-Fadilah ".

Adapun teknik pengumpulan data yang digunakan dalam penelitian ini adalah teknik Angket (Kuesioner), Wawancara (Interview), dan Studi Dokumentasi.

\section{Pembahasan dan Hasil Penelitian : Kinerja Guru}

\section{Pengertian Kinerja Guru}

Pengertian kinerja Guru mengacu pada pengertian "Performance" yang diterjemahkan menjadi kinerja, juga berarti prestasi kerja atau pelaksanaan kerja/penampilan kerja. Dengan demikian kinerja adalah penampilan perilaku kerja yang ditandai oleh keluwesan gerak, ritme dan urutan kerja yang sesuai dengan prosedur sehingga diperoleh hasil yang memenuhi syarat kualitas, kecepatan dan jumlah. (LAN, 1992,p.3).

Kinerja Guru memerlukan suatu sistem manajemen kinerja yang dirancang untuk menghubungkan tujuan institusional (lembaga) dengan tujuan dalam proses pembelajaran, sehingga pemahaman bersama mengenai apa yang harus dicapai dan bagaimana mengatur orang dengan cara yang tepat untuk mencapai suatu tujuan. Kinerja dapat juga disamakan dengan efektivitas, daya guna, atau produktivitas, oleh karena merupakan ukuran upaya yang dilakukan untuk meraih hasil yang diperoleh, yaitu dengan membandingkan hasil yang dicapai (prestasi) terhadap besarnya upaya yang telah diberikan untuk itu. Lain lagi halnya dengan (Sedarmayanti,2004,p.5), bahwa :Kinerja adalah hasil dari fungsi suatu pekerjaan atau kegiatan tertentu selama periode tertentu. Sesuai pengertian ini terdapat tiga aspek yang perlu dipahami, yaitu:

a) Kejelasan tugas atau pekerjaan yang menjadi tanggung jawabnya; 
b) Kejelasan hasil yang diharapkan dari pekerjaan atau fungsi; dan

c) Waktu untuk menyelesaikan pekerjaan agar hasil dapat terwujud.

\section{Faktor-faktor yang mempengaruhi kinerja Guru}

P. Drucker (1999) mengemukakan, bahwa dalam mengendalikan kinerja (performanse) karyawan/pegawai, mempunyai lima dimensi, yaitu :

a) Dimensi Fisiologis, yaitu dimensi yang menunjuk, bahwa manusia akan bekerja dengan baik, bila bekerja dalam berbagai ragam tugas-tugas dan ritme kecepatan yang disesuaikan dengan fisiknya.

b) Dimensi Psikologis, yaitu dimensi yang merupakan aspek-aspek kepribadian. Seseorang memperoleh kepuasan pekerjaan, manakala menyenangi pekerjaannya.

c) Dimensi Sosial, yaitu dimensi yang mengacu pada suatu ungkapan hubungan sosial di antara sesama karyawan, seperti terjadi konflik dalam suatu organisasi atau kelompoknya;

d) Dimensi ekonomi, yaitu dimensi yang ada hubungannya dengan kehidupan karyawan. Upah atau imbalan jasa yang tidak sesuai dengan pekerjaannya, akan menghambat terhadap kinerja yang dilakukannya;

e) Dimensi keseimbangan, yaitu dimensi yang ada hubungannya dengan keseimbangan antara apa yang diperoleh dari pekerjaanya dengan kebutuhan hidupnya.

Dari dimensi-dimensi kinerja karyawan/pegawai, faktor-faktor yang mempengaruhi kinerja Guru dalam tugastugas kependidikan sebagai tugas profesional, sangat dipengaruhi oleh faktor-faktor keberhasilan dalam proses pembelajaran / proses belajar mengajar (PBM) di kelas (sekala mikro), maupun dalam lingkungan institusional atau lembaga (sekala messo). Kinerja Guru mengacu pada kemampuan-kemampuan atau kompetensi yang dilakukan oleh Guru dalam proses pembelajaran, baik di dalam maupun di luar lingkungan sekolah. Kaitannya dengan kinerja Guru dalam pelaksanaan pembelajaran, Georgia Departement of Education telah mengembangkan Teacher Performance Assessment Instrument yang kemudian dimodifikasi oleh Departemen Pendidikan Nasional (2002) menjadi Alat Penilaian Kemampuan Guru (APKG). Instrument atau alat penilaian ini menyoroti tiga aspek utama kemampuan sebagai 
salah satu faktor yang mempengaruhi terhadap kinerja Guru yang harus dimilikinya, yaitu rencana pengajaran (Teaching Plans and Materials), Prosedur mengajar (Classroom Procedure), dan hubungan antar pribadi (Interpersonal Skill) di samping faktor Motivasi, kebutuhan, atau dorongan membuat seseorang itu berprilaku.

Departemen Pendidikan Nasional (Depdiknas) menegaskan dalam Pedoman Pelaksanaan Pola Pembaharuan Sistem Pendidikan Tenaga Kependidikan di Indonesia, profil penampilan mengajar tenaga edukatif dapat diidentifikasi dengan menggunakan pendekatan Pendidikan Guru Berdasarkan Kompetensi (PGBK) atau Competency Based Teacher Education (CBTE) yang meliputi sepuluh kemampuan dasar Guru. Kemampuan dasar Guru itu, sebagai berikut ${ }^{1}$ :

1. Kemampuan menguasai bahan pengajaran;

2. Kemampuan mengelola program belajar mengajar;

3. Kemampuan mengelola kelas;

4. Kemampuan menggunakan media dan sumber pelajaran;

5. Kemampuan menguasai landasan-landasan kependidikan;

6. Kemampuan mengelola interaksi belajar mengajar;

7. Kemampuan menilai prestasi siswa untuk kepentingan pengajaran;

8. Kemampuan mengenal fungsi dan program pelayanan Bimbingan dan Penyuluhan;

9. Kemampuan mengenal dan menyelenggarakan administrasi sekolah;

10. Kemampuan memahami prinsip-prinsip dan menafsirkan hasil-hasil penelitian pendidikan guna keperluan pengajaran.

Secara garis besar berbagai kemampuan yang dimiliki oleh Guru, dapat saya simpulkan menjadi tiga kemampuan dasar Guru, yaitu : (1) Kemampuan merencanakan pembelajaran; (2) Kemampuan melaksanakan pembelajaran; dan (3) Kemampuan mengevaluasi (pengawasan) pembelajaran. Dari ketiga unsur ini diharapkan memiliki motivasi kinerja Guru yang tinggi dalam meningkatkan kualitas hasil belajar siswa, khususnya di SMA Negeri Kabupaten Garut. Suatu motivasi cenderung mengurangi kekuatannya, manakala tercapainya suatu kepuasaan itu

\footnotetext{
${ }^{1}$ (Depdiknas, 2002, P. 43).
} 
terhalang, perbedaan kognisi, frustasi, atau karena kekuatan motivasinya bertambah. Perubahan-perubahan kekuatan motivasi tersebut, secara singkat penulis kemukakan sebagai berikut:

a) Kepuasaan kebutuhan, yaitu kepuasan yang mengacu pada kebutuhan yang apabila terpenuhi/terpuaskan, maka kebutuhan tersebut dianggap tercapai dan kedudukannya dalam kompetisi dengan kebutuhan-kebutuhan lainhya berubah menjadi rendah tingkatannya;

b) Terhalangnya pemuasan kebutuhan, berubahnya suatu kebutuhan dari kebutuhan selain ditentukan oleh terpuasnya kebutuhan tersebut, dapat pula karena terhalangnya usaha pencapaian tujuan tersebut. Perilaku ini cenderung terikat pada perilaku mengatasi, yakni suatu usaha untuk memilih suatu keputusan dengan cara coba dan mencoba (trial and error) yang sekiranya menghilangkan halangan;

c) Perbedaan Kognisi, yaitu perbedaan yang menunjuk pada mendorong seseorang untuk berbuat seesuatu. Perbedaan ini meliputi ketidakserasian, ketidakharmonisan, ketidakserasian, dan kontradiksi antara dua hal. Hubungan perbedaan ini muncul, bila dua hal yang tidak bisa bersama-sama muncul secara bersamaan ;

d) Frustasi, yaitu terhalangnya/gagalnya suatu usaha pencapaian tujuan. Gejalanya cenderung lebih tepat sebagai usaha kondisi yang melekat pada diri seseorang dibandingkan dengan usaha mencari sebabnya dari lingkungan.

e) Seseorang menjadi frustasi, karena halangan-halangan yang sifatnya imajiner, bukan pada halangan-halangan yang sifatnya riil ;

f) Kekuatan motivasi yang bertambah, yaitu prilaku akan berubah manakala kebutuhan-kebutuhan yang menarik, bertambah kekuatannya. Kekuatan dari beberapa kebutuhan akan nampak dalam pola lingkaran (cyclical pattern).

g) Perubahan tersebut merupakan acuan dalam peningkatan kinerja tenaga kependidikan, khususnya kinerja Guru dalam proses pembelajaran/proses belajar mengajar (PBM), sehingga kualitas hasil belajar di sekolah senantiasa ditingkatkan. 
Sebagai bahan acuan untuk mengukur kinerja Guru dan sekaligus sangat berkaitan dengan kinerja sekolah dalam peningkatan kualitas hasil belajar siswa yang mengacu pada peningkatan kualitas sekolah, Departemen Pendidikan Nasionan melalui Surat Keputusan Menteri Pendidikan Nasional Republik Indonesia Nomor 135/U/2004 tanggal 18 Oktober 2004, telah menetapkan tentang Standar Pelayanan Minimal Bidang Pendidikan, khususnya Pendidikan Menengah, sebagai berikut ${ }^{2}$ :

1) Standar Pelayanan Minimial (SPM) Pendidikan Sekolah Menengah Atas (SMA)/Madrasah Aliyah (MA), terdiri dari:

2) 60 persen anak dalam kelompok usia 16-18 tahun bersekolah di SMA/MA dan SMK;

3) Angka Putus Sekolah (APS) tidak melebihi 1 persen dari jumlah siswa yang bersekolah;

4) 90 persen sekolah memiliki sarana dan prasarana minimal sesuai dengan standar teknis yang ditetapkan secara nasional;

5) 80 persen sekolah memiliki tenaga kependidikan non guru untuk melaksanakan tugas administrasi dan kegiatan non mengajar lainnya;

6) 90 persen dari jumlah guru SMA/MA yang diperlukan terpenuhi;

7) 90 persen guru SMA/MA memiliki kualifikasi sesuai dengan yang ditetapkan secara nasional;

8) 100 persen siswa siswa memiliki buku pelajaran yang lengkap setiap mata pelajaran;

9) Jumlah siswa SMA/MA per kelas antara 30 - 40 siswa;

10) 90 persen dari siswa yang mengikuti uji sampel mutu standar nasional mencapai nilai "memuaskan" dalam mata pelajaran bahasa Inggris, Geografi, Matematika Dasar untuk kelas I, dan

11) 25 persen dari lulusan SMA/MA melanjutkan ke Perguruan Tinggi yang terakreditasi.

\section{Komitmen Guru pada Tugas}

Sebagaimana yang diamanatkan dalam Undang Undang Sistem Pendidikan Nasional (UUSPN) tahun 2003,

2 (SK. Mediknas No.135 tahun 2004 pasal 4). 
bahwa Pendidikan adalah usaha sadar dan terencana untuk mewujudkan suasana belajar dan proses pembelajaran agar peserta didik secara aktif mengembangkan potensi dirinya untuk memiliki kekuatan spiritual keagamaan, pengendalian diri, kepribadian, kecerdasan, akhlak mulia, serta ketrampilan yang diperlukan dirinya, masyarakat, bangsa dan negara. (UUSPN, 2003, p. 2

Kalau kita perhatikan dari pernyataan tersebut di atas, betapa beratnya peranan sebagai Guru dengan tugas-tugas dan komitmennya yang tinggi. Oleh karena figur seorang Guru mempunyai tugas yang sangat berat dengan berbagai komitmennya, bukan hanya dituntut menanamkan aspek pengetahuan (kognitif), melainkan lebih menitikberatkan pada aspek keagamaan, nilai, moral, dan sikap (affektif), di samping ketrampilan (psikomotorik) kepada peserta didik, maka Profesionalisme Guru senantiasa ditingkatkan. Itu sebabnya peranan dan tugas Guru dengan berbagai komitmennya sangat komplek, dari sudut pandang mana yang digunakan dalam melihatnya.

Secara garis besar, tugas guru terbagi menjadi tiga, yaitu tugas Profesional, Kemanusiaan, dan Kemasyarakatan.

1. Tugas Profesional, menunjuk pada pekerjaan yang memerlukan keahlian khusus sebagai guru. Tugas ini tidak dapat dilakukan oleh sembarang orang di luar bidang kependidikan. Tugas Guru sebagai profesi meliputi tugas: mendidik, mengajar, dan melatih. Mendidik berarti meneruskan dan mengembangkan nilai-nilai kehidupan. Tugas Mengajar berarti meneruskan dan mengembangkan ilmu pengetahuan dan teknologi, sedangkan tugas Melatih berarti mengembangkan ketrampilan-ketrampilan dan penerapannya pada siswa.

2. Tugas Kemanusiaan, menunjuk pada tugas menjadikan dirinya sebagai orang tua kedua. Ia harus mampu menarik simpati sehingga ia menjadi idola para siswanya. Ia harus mempertahankan kepribadian di dalam meningkatkan nilai-nilai hidup menjadi manusia Indonesia seutuhnya dan ia harus mampu mentransformasikan dirinya pada kepentingan anak;

3. Tugas Kemasyarakatan, menunjuk pada tugas pada tempat yang lebih terhormat di lingkungannya, karena dari seorang Guru, mempunyai tugas dan mendidik dan 
mengajar masyarakat untuk menjadi warga Indonesia bermoral Pancasila, di samping tugas secara umum mencerdaskan kehidupan bangsa Indonesia. Hal ini diharapkan masyarakat dapat memperoleh ilmu pengetahuan. Ini berarti Guru membuka jendela cakrawala masyarakat dalam mencerdaskan kehidupan masyarakat.

Berkaitan dengan komitmen Guru pada tugas, nampaknya tugas dan kompetensi Guru merupakan prasarat yang harus dimiliki bagi seorang Guru yang profesional. Lebih tegas dalam Undang-Undang Guru dan Dosen, bahwa Guru harus memiliki kompetensi Pedagogik, Kepribadian, Profesional, dan Sosial.

a) Kompetensi Pedagogik, yaitu kemampuan-kemampuan yang harus dimiliki Guru dalam mengelola pembelajaran peserta didik.

b) Kompetensi Kepribadian, yaitu kemampuan-kemampuan kepribadian yang harus dimiliki Guru terutama kepribadian yang mantap, berakhlak mulia, arif, dan berwibawa, serta menjadi teladan peserta didik, yakni pribadi yang di GUGU dan DITIRU (GURU).

c) Kompetensi Profesional, yaitu kemampuan-kemampuan yang harus dimiliki Guru dalam hal penguasaan materi pembelajaran secara luas dan mendalam.

d) Kompetensi Sosial, yaitu kemampuan-kemampuan yang harus dimiliki Guru untuk berkomunikasi dan berinteraksi secara efektif dan efisien dengan peserta didik, sesama Guru, orang tua/wali peserta didik, dan masyarakat sekitar.

\section{Kualitas Hasil Belajar Siswa}

Kualitas hasil belajar siswa menunjuk pada hasil yang telah dicapai, dari yang telah dilakukan atau dikerjakan siswa pada proses pembelajaran. Hal ini merupakan suatu indikator, baik atau buruknya dari pengaruh gaya kepemimpinan Kepala Sekolah, kejelasan Visi dan Misi, komitmen guru pada tugas dan kondisi latar belakang sosial, ekonomi, dan budaya terhadap kinerja Guru, tetap fokusnya pada kualitas hasil belajar siswa, apakah kualitas pada bidang akademik maupun non akademik di sekolah, yang dapat memberikan kepuasan bukan hanya pada diri siswa itu sendiri, namun pada Guru, atau tenaga kependidikan lainnya, maupun pada orang tua siswa (masyarakat). 
Memahami tentang kualitas hasil belajar siswa berarti memahami tentang bagaimana gaya kepemimpinan yang diterapkan, kejelasn Visi dan Misi, komitemen guru pada tugas, dan latar belakang sosial, ekonomi, dan budaya, berpengaruh terhadap kinerja guru yang positif dalam proses pembelajaran di Sekolah.

Engkoswara (1987) mengemukakan, bahwa "hasil atau produk pendidikan yang dilihat dari hasil belajar siswa adalah dalam bentuk-bentuk: "Kognitif, Afektif, Konatif, Konsep Kepribadian, Konsep Diri, Kreativitas, Penyesuaian Diri, Kematangan Kerja, dan Tanggung Jawab Kemasyarakatan".

Kualitas hasil belajar siswa yang dimaksud dalam hal ini, yaitu kualitas hasil belajar siswa yang memberikan kepuasan kepada Guru, Kepala Sekolah, tenaga kependidikan lainnya, orang tua siswa, dan siswa itu sendiri yang ditinjau dari indikator dan dapat diukur, antara lain dari :

1. Nilai akademik, meliputi Nilai Ujian Nasional (UN), nilai Ujian Sekolah (US), dan Nilai Harian (formatif/subsumatif);

2. Nilai non akademik meliputi nilai kegiatan ekstrakurikuler yang dilakukan oleh siswa dan sangat menunjang kegiatan kurikuler, seperti siswa mengikuti kegiatan Kepramukaan, Paskibra, PMR, KIR, Olah Raga, kesenian dan lain-lain.

Pada penelitian ini, penulis memfokuskan pada beberapa kualitas hasil belajar siswa yang mengacu pada nilai Ujian Nasional (UN) dan nilai Ujian Sekolah (US) siswa MA Al-Fadilah Kelas III pada setiap program pada tahun pelajaran 2016/2017 sampai dengan 2017/2018 dan kegiatan yang sangat menunjang kegiatan kurikuler (Ko kurikuler) serta kegiatan ekstra kurikuler, sehingga kajiannya sangat spesifik dan mudah diukur serta sangat berdampak pada peningkatan mutu pendidikan dan peningkatan mutu sumber daya manusia atau Indeks Pembangunan Manusia (IPM) pada sektor Pendidikan di Kabupaten Garut.

Hasil belajar siswa ini akan memberikan gambaran yang jelas terhadap indikator rata-rata nilai setiap mata pelajaran maupun terhadap klasifikasi sekolah yang bersangkutan. Ini pula yang akan menentukan, bahwa gaya kepemimpinan Kepala Sekolah, kejelasan Visi dan Misi, komitmen guru pada tugas, dan latar belakang sosial, ekonomi, dan budaya dianggap berhasil dalam 
mempengaruhi kinerja Guru, oleh karena dampaknya terhadap peningkatan kualitas hasil belajar siswa MA AlFadilah .

\section{Penutup}

Perubahan implementasi manajemen stratejik dalam bidang pendidikan, yang fokusnya pada kinerja Guru, kejelasan Visi dan Misi Sekolah, aplikasi gaya kepemimpinan Kepala Sekolah, Komitmen Guru pada tugas, dan latar belakang Sosekbud sekolah/masyarakat, serta kualitas hasil belajar siswa pada tataran institusional (sekolah), perlu mendapat perhatian yang sangat serius. Oleh karena keberhasilan manajemen pendidikan ada pada sekolah, di mana pada sekolah itu terdapat proses pembelajaran di kelas (Mikro) sebagai pusat terjadinya kegiatan belajar mengajar antara Siswa dengan Guru.

Pada kenyataanya upaya peningkatan kualitas hasil belajar siswa sangat berpengaruh terhadap peningkatan mutu pendidikan dan sangat berpengaruh juga pada peningkatan Sumber Daya Manusia (SDM), bukan hanya pada tataran Mikro (kelas), yaitu manajemen proses pendidikan unit kecil dalam waktu yang relatif singkat, misalnya dalam tiap pertemuan kegiatan belajar mengajar di kelas sekitar satu atau dua jam pelajaran, namun pada tataran Messo (institusional), yaitu manajemen pendidikan kelembagaan atau satuan pendidikan seperti dalam lingkungan keluarga, masyarakat, atau sekolah bahkan juga pada tataran Makro (daerah, nasional, dunia), yaitu manajemen pendidikan yang mengkaji keterkaitan yang utuh antara kecenderungan kehidupan dengan kemampuan kualitas kemandirian manusia Indonesia dan rambu-rambu pembekalan dalam suatu sistem pendidikan.

Peningkatan kualitas hasil belajar siswa tersebut memerlukan perubahan sistem dan mekanisme implementasi manajemen stratejik pendidikan, terutama disebabkan oleh banyaknya keterbatasan dan kelemahan yang ada dalam manajemen pendidikan di tataran sekolah. Di sisi lain, di luar sekolah (masyarakat) dalam berbagai bidang terjadi perubahan yang begitu cepat, yang menuntut adanya perubahan dalam penyelenggaraan/manajemen pendidikan. Tuntutan permintaan masyarakat terhadap pendidikan yang bermutu itu, terus menerus dihadapkan kepada semua warga sekolah yang senantiasa termotivasi untuk meningkatkan kinerjanya yang optimal 
terhadap semua tenaga kependidikan di sekolah terutama kinerja Guru dan Kepala Sekolah.

Ada beberapa faktor lain yang mempengaruhi peningkatan kinerja Guru, di samping kejelasan Visi dan Misi Sekolah, Pengaruh Gaya Kepemimpinan Kepala Sekolah, Komitmen Guru pada tugas, dan latar belakang sosekbud sekolah/masyarakat, sehingga kualitas hasil belajar siswa meningkat, diantaranya adalah:

1. Kondisi fisiologis Guru dalam pelaksanaan proses pembelajaran;

2. Kondisi psikologis Guru dalam pencapaian kepuasaan kualitas hasil belajar siswa;

3. Kondisi Sosial, ekonomi, dan budaya Guru yang harmonis terhadap lingkungan sekolah;

4. Kondisi keseimbangan dalam memenuhi kebutuhan hidup sesuai dengan profesinya;

5. Tingkat kematangan siswa;

6. Biaya pendidikan yang mendukung/mencukupi terhadap kesejahteraan Guru;

7. Sarana dan prasarana pendidikan yang menunjang dalam proses pembelajaran; dan

8. Karakteristik Kultur Sekolah (School Culture's).

Pengumpulan data dilakukan melalui penyebaran Angket (Kuesioner) terhadap 30 responden (guru) dari populasi 40 orang, dan para siswa yang berprestasi, masing-masing kelas sebanyak 3 orang ( $14 \mathrm{X} 3=42$ orang).

Pengumpulan data ini dianggap representatif dan valid, oleh karena dapat menunjukkan reliabilitas (keajegan) dan validitas (ketepatan) responden dalam menjawab pertanyaanpertanyaan / pernyataan-pernyataan angket dan wawancara sehingga dapat dijadikan alat ukur yang sebenarnya.

Analisis item angket dilakukan oleh penulis dengan tujuan untuk mengetahui kualitas isi, apakah dapat dimengerti dan ditafsirkan secara sama oleh responden. Cara menganalisis item tersebut dengan perhitungan daya pembeda (item discriminality), yaitu konsistensi skor item dengan skor keseluruhan dengan perhitungan Korelasi Pearson Product Moment. Koefisien korelasi yang lebih besar dari 0,599 dipandang konsisten dan yang kurang dari 0,60 harus direduksi untuk diperbaiki. Hal ini lebih tegas dikatakan Kaplan (1983), bahwa makin tinggi nilai koefisien korelasi berarti besar 
hubungan antara item dengan variabel yang diteliti semakin kuat dan konsistensi.

Lebih jelasnya pedoman untuk memberikan interpretasi koefisien korelasi dapat dilihat pada interval koefisien berikut ini -

Tabel 1.1

KOEFISIEN KORELASI

\begin{tabular}{|c|c|c|}
\hline No. & Interval koefisien & Tingkat pengaruh/hubungan \\
\hline \hline 1 & $0,00-0,199$ & Sangat Rendah \\
\hline 2 & $0,20-0,399$ & Rendah \\
\hline 3 & $0,40-0,599$ & Sedang \\
\hline 4 & $0,60-0,799$ & Kuat \\
\hline 5 & $0.80-1,000$ & Sangat Kuat \\
\hline
\end{tabular}

Secara garis besar pengumpulan data dapat dilihat pada instrumen penelitian yang ditujukan pada tabel berikut ini :

Tabel 1.2

RINGKASAN KISI-KISI INSTRUMEN PENELITIAN

\begin{tabular}{|c|c|c|c|c|}
\hline No & $\begin{array}{l}\text { Variabel } \\
\text { penelitian } \\
\end{array}$ & $\begin{array}{l}\text { Komponen } \\
\text { yang diukur }\end{array}$ & $\begin{array}{l}\text { No item } \\
\text { instrumen }\end{array}$ & Ket \\
\hline 1 & $\begin{array}{l}\text { Komitmen } \\
\text { guru pada } \\
\text { tugas }\end{array}$ & $\begin{array}{l}\text { Tugas } \\
\text { Profesional : } \\
\text { Tugas guru } \\
\text { mendidik } \\
\text { Tugas guru } \\
\text { mengajar } \\
\text { Tugas guru } \\
\text { melatih } \\
\text { Tugas } \\
\text { Kemanusiaan } \\
\text { Tugas } \\
\text { Kemasyarakata } \\
\mathrm{n}\end{array}$ & $\begin{array}{l}29,30,33, \\
34,35,36, \\
37,38,39, \\
40,41,42, \\
43 \\
31 \\
32\end{array}$ & 15 item \\
\hline 2. & Kinerja guru & $\begin{array}{l}\text { Kemampuan } \\
\text { merencana- kan } \\
\text { pembelajaran; } \\
\text { Kemampuan } \\
\text { melaksana- kan }\end{array}$ & $\begin{array}{l}51,52,53, \\
54,55,56, \\
57 \\
58,59,60, \\
61,62,63,\end{array}$ & 25 item \\
\hline
\end{tabular}




\begin{tabular}{|l|l|l|l|l|}
\hline No & $\begin{array}{l}\text { Variabel } \\
\text { penelitian }\end{array}$ & $\begin{array}{l}\text { Komponen } \\
\text { yang diukur }\end{array}$ & $\begin{array}{l}\text { No item } \\
\text { instrumen }\end{array}$ & Ket \\
\hline \hline & & pembelajaran; & 64 & \\
& & Kemampuan & & \\
& & mengevalu- asi, & $65,66,67$, & \\
& & Menganalisis, & 68,69, \\
& & dan & $70,71,72,7$ & \\
& & Perbaikan/Peng & $3,74,75$ & \\
& & ayaan & & \\
& & Remedial/Enri & & \\
& & chment & & \\
& & Teaching) & & \\
& & Pembelajaran. & & \\
& &
\end{tabular}

Mengingat data yang dikumpulkan dalam penelitian ini masih merupakan data mentah/lunak (soft data), maka harus disusun, diklasifikasikan, diolah dan dianalisis menurut teknik/prosedur tertentu. Oleh karena itu data yang dikumpulkan melalui teknik Angket (Kuesioner), Wawancara (Interview), dan Studi Dokumentasi dalam penelitian kuantitatif harus validitas (internal/eksternal), reliabilitas, dan objektivitas.

Validitas internal (kredibilitas) menunjuk pada apakah instrumen sungguh-sungguh mengukur variabel yang sebenarnya, yaitu kebenaran data yang diperoleh dengan instrumen atau kesesuaian konsep per responden. Validitas eksternal (transferabilitas, applicabilitas), menunjuk pada kaitan generalisasi, yakni hingga manakah generalisasi yang dirumuskan berlaku bagi kasus-kasus lain di luar penelitian atau dapat diterapkan oleh orang lain pada situasi lain.

Reliabilitas (depentabilitas), menunjuk pada adanya konsistensi, yakni memberikan hasil yang konsisten atau kesamaan hasil, sehingga dapat dipercaya sehubungan dengan apakah penelitian itu dapat diulangi atau direplikasi oleh peneliti lain dengan hasil yang konsisten.

Objektivitas (konfirmabilitas), menunjuk bila hasil penelitian sama, siapapun penelitinya. Objektivitas terdapat, bila hasil penelitian dapat dibenarkan atau dikonfir oleh peneliti lain. Dengan kata lain berusaha untuk sedapat mungkin memperkecil subyektivitas

Berkaitan dengan teknik pengolahan data dalam penelitian, perlu adanya analisis data kuantitatif yang mudah ditafsirkan. 
Hal ini pula ditegaskan, bahwa Analisis data kuantitatif adalah proses menyusun data, berarti menggolongkannya dalam pola, tema, atau ketegori agar dapat ditafsirkan. Tanpa kategorisasi atau klasifikasi data akan terjadi chaos. Tafsiran atau interpretasi artinya memberikan makna kepada analisis, menjelaskan pola atau kategori, mencari hubungan antara berbagai konsep. Interpretasi menggambarkan perspektif atau pandangan peneliti, bukan kebenaran. Kebenaran hasil penelitian masih harus dinilai orang lain dan diuji dalam berbagai situasi lain.

Dengan demikian proses analisis data kuantitatif memerlukan daya kreatif dan kemampuan intelektual yang tinggi dari peneliti untuk mengolah data tersebut, sehingga diketahui maknanya.

Kita ketahui dalam situasi sosial pada hakekatnya bersifat unik dan tidak dapat direkonstruksi sepenuhnya seperti semula. Oleh karena itu untuk menjamin kebenaran dan objektivitas hasil penelitian kuantitatif ini dilakukan "Audit Trail", yakni melakukan pemeriksaan untuk meyakinkan bahwa hal-hal yang dilaporkan betul-betul terjadi sesuai dengan kenyataan yang ada di lapangan. Begitu pula dilakukan "Triangulasi" yakni untuk mengecek kebenaran data dengan membandingkannya dengan data yang diperoleh dari nara sumber lain.

Upaya yang dilakukan dalam triangulasi ini adalah: membandingkan hasil pengumpulan data melalui Angket (Kuesioner) dan Wawancara (Interview) dengan hasil pengamatan; dan memperbanyak sumber data melalui Studi Dokumentasi dari setiap fokus penelitian.

Adapun langkah-langkah yang dilakukan meliputi: Seleksi Angket dan Pembobotan

Angket yang telah dikembalikan dari responden (Guru MA Al-Fadilah ), diperiksa jumlahnya dan kelengkapan isinya berdasarkan substansi yang ada pada variabel penelitian, yaitu variabel kejelasan Visi dan Misi, gaya kepemimpinan Kepala Sekolah, komitmen Guru pada tugas, latar belakang sosekbud, dan kinerja Guru serta variabel kualitas hasil belajar siswa MAN yang berada di Wilayah Kabupaten Garut. Alat ukur yang digunakan dalam penelitian yang berbentuk daftar isian dan angket (kuesioner) ini, menentukan pembobotan yang dijadikan sebagai arah untuk menentukan seberapa besar pengaruh dan signifikansinya dari variabel bebas (variabel independet/ stimulus, prediktor/ antecedent) terhadap variabel terikat 
(variabel dependent/ output/ kriteria/ konsekuen/ dipengaruhi), juga sebagai landasan dalam mempertimbangkan analisis statistik, artinya dalam pengujian hipotesis yang didasarkan pada tingkat pengaruh/hubungan itu terdapat hubungan apakah sangat rendah, rendah, sedang, kuat, atau sangat kuat.

Pembobotan dalam penelitian ini yang didasarkan pada alat ukur angket (kuesioner) berupa pernyataan atau pertanyaan, penulis gunakan berdasarkan pembobotan skala likert. Skala ini digunakan, dengan alasan untuk mengukur sikap, pendapat, atau persepsi seseorang atau kelompok tentang fenomena/gejala sosial yang sedang berkembang pada saat penelitian ini dilakukan.

Pernyataan/pertanyaan berskala dan jawaban (option) yang dibuat menurut skala sikap berbentuk pilihan ganda dalam lima kategori, dari jawaban tidak pernah sampai selalu atau dari sangat tidak setuju sampai dengan sangat setuju.

Untuk memudahkan pengolahan data maka jawaban diidentifikasi dengan sistem skor skala dari 1 sampai 5, yaitu :

S (Selalu) atau SS (Sangat Setuju) diberi skor

$$
=5
$$

SR (Sering) atau S (Setuju) diberi skor

$$
=4
$$

J (Jarang) atau R (Ragu-ragu) diberi skor

$$
=3
$$

JK (Jarang Sekali) atau TS (Tidak Setuju) diberi skor

$$
=2
$$

TP (Tidak Pernah) atau STS (Sangat Tidak Setuju) diberi skor

$$
=1
$$

Perhitungan dilakukan dengan menggunakan komputer, dengan bantuan Statistical Product and Service Salvations (SPSS) 10.0 versi 10.0 For Windows.

Langkah Pengolahan Data Statistik dengan Program SPSS 10.0 For Windows

a) Penyajian Data

Setelah data terkumpul dan telah ditabulasi serta diberi bobot tertentu maka proses pengolahan data disajikan sebagai berikut : 
1) Data dimasukkan pada program SPSS 10.0 For Windows melalui menu-menu untuk menentukan: mean, median, mode, standar deviasi, variance, range, standar error of mean, percentiles, kurtosis (keruncingan), frecuency, percent, valid percent, cumulative percent, dan lain-lain, serta aktualisasi dalam bentuk diagram seperti diagram batang/histogram.

2) Uji validitas dan reliabilitas dengan alpha cronbach, yaitu untuk menentukan standar reliabilitas angket dengan menu skala reliability;

3) Uji asumsi regresi berganda, yaitu menguji apakah dalam model regresi terjadi ketidaksamaan varians dan residual dari suatu penelitian ke penelitian lain. Begitu pula dalam regresi ini, apakah variabel independent, variabel dependent atau keduanya mempunyai distribusi normal atau tidak.

b) Identifikasi dan analisis faktor

Mengingat data mentah berupa data ordinal yang ditransformasikan merupakan data non parametrik, maka uji korelasinya menggunakan uji korelasi Pearson Product Moment.

Analisis penelitian dengan menggunakan uji korelasi ini bertujuan untuk menganalisis pengaruh empirik keadaan sekolah yang didasarkan pada pengaruh kejelasan Visi dan Misi, gaya kepemimpinan Kepala Sekolah, komitemn Guru pada tugas, dan latar belakang sosekbud terhadap kinerja Guru dan hubungannya dengan kualitas hasil sbelajar siswa MA Al-Fadilah pada tahun pelajaran 2016/2017 sampai dengan 2017/2018.

Rumus yang digunakan untuk mengolah data kuantitatif ini menggunakan rumus uji signifikansi Korelasi Pearson Product Moment, yaitu :

$$
\operatorname{rxy}=\frac{n \sum x_{1} y_{1}-\left(\sum x_{1}\right)\left(\sum y_{1}\right)}{\sqrt{\left.\left\{n \sum x_{1}^{2}-\left(\sum x_{1}\right)^{2}\right\} n \sum y_{1}^{2}-\left(y_{1}\right)^{2}\right\}}}
$$




\section{Daftar Pustaka}

Akdon, (2006), Strategic Management for Educational Management (Manajemen Strategik untuk Manajemen Pendidikan), Bandung : CV. Alfabeta.

Anwar, Moch. Idochi., (2003), Administrasi Pendidikan dan Manajemen Biaya Pendidikan (Teori, Konsep, dan Isu), Bandung : CV Alfabeta

Arikunto, Suharsimi, (1998), Prosedur Penelitian, Suatu Pendekatan Praktek, Jakarta: CV. Rineka Cipta.

Atmodiwirio, Soebagio dan Totosiswanto, Soeranto (1991), Kepemimpinan Kepala Sekolah, Semarang: CV. Adhi waskita

Bagastawa, Saptadi, (2004), Manager as Leader, Yogyakarta: PT. Amara Books

Barnes, Tony, (1998), Kaizen Strategies for Successful Leadership, Japan: Europe Japan Center.

Blanchard, Kenneth H. \& Hersey, Paul, (1982), Management of Organizational Behavior, Terjemahan (1986), Jakarta: PT. Erlangg

Boles, Harorl W., And Davenport, James A, (1993), Introductional to Educational Leadership, Lanham: University Press of America

Burhan Bungin, H. M., (2005), Metodologi Penelitian Kuantitatif, Jakarta: Prenada Media.

Bush, Tony and Coleman, Marianne, (2000), Leadership and Strategic Management in Education, LeicesterInggris:EMDU(Educational Management Development Unit) - University of Leicester.

Casson, Herbert N., (1996), Bagaimana seharusnya jadi Pemimpin, Bandung: PT Al Ma'arif.

Chandra, Robby Iap., (2007), Apa itu Kepemimpinan, [online] Tersedia: E-mail: webmaster@sabda.org (17 Maret 2007).

Cohen, William A., (1992), Alih bahasa, Adiwiyoto, Seni Kepemimpinan, Jakarta: CV. Mitra Utama.

Cooper, Robert K. and Sawaf, Ayman, (1997), EXECUTIVE EQ, Emotional Intelligence in Leadership and Organizations, New York : A member of Penguin Putnam Inc.

Covey, Stephen R., (1996), Principle Center Leadership, USA: Covey Leadership Center. 

, (1993), The 7 Habits of Highly Effective People, USA: Simon \& Schuster Inc.

Creswell, Jhon W., (1994), Research Design: Qualitative \& Quantitative Approaches, London-New Delhi: SAGE Publications.

Danim, Sudarwan, (2002), Inovasi Pendidikan Dalam Upaya Peningkatan Profesionalisme tenaga Kependidikan, Bandung: Pustaka Setia.

Depdiknas, (2002), Manajemen Peningkatan Mutu Berbasis Sekolah, Jakarta: Dirjen Dikdasmen-Direktorat SLTP.

Depdiknas, (2005), Kurikulum 2004 Sekolah Menengah Atas (SMA), Pedoman Khusus Pengembangan Silabus Berbasis Kompetensi Siswa Sekolah Menengah Atas (SMA), Jakarta : CV. Binatama Raya.

Drucker, Peter F, (1999), Management Challenges for the $21^{\text {th }}$ Century, New York: Harper Collins Publisher

Engkoswara, (1999), Menuju Indonesia Modern 2020, Bandung: Yayasan Amal Keluarga.

-----------, (2001), Paradigma Manajemen Pendidikan menyongsong Otonomi Daerah, Bandung: Yayasan Amal Keluarga.

---------, (2002), Lembaga Pendidikan sebagai Pusat Pembudayaan, Bandung: Yayasan Amala Keluarga.

Fattah, Nanang, (2000), Manajemen Berbasis Sekolah, Bandung: CV ANDIRA.

----------, (2000), Ekonomi dan Pembiayaan Pendidikan, Bandung : PT Remaja Rosda Karya. , (2002), Landasan Manajemen Pendidikan, Bandung: PT Remaja Rosda Karya.

Fiedler, Fred E., (1967), Theory of Leadership Effectiveness, New York: Mc. Gra-Hill.

Freedman, Mike dan Tregoe, Benjamin B., (2004), The ART and Discipline of Strategic Leadership, Pemikiran Strategis untuk Merealisasikan Visi Organisasai, Jakarta: Gramedia Pustaka Utama.

Gaffar, Mohammad Fakry, (1987), Perencanaan Pendidikan, Teori dan Metodologi, Jakarta: P2LPTKDitjen DiktiDepdikbud.

(1987), Beberapa Fenomena dalam mengembangkan Kepemimpinan Pendidikan Khas Indonesia, pada temu pendapat ISPI, Bandung: IKIP Bandung. 
Gibson, Ivancevich, dan Donnelly, (1997), Organisasi, Perilaku, Struktur, Proses, Jakarta: CV. Binarupa Aksara.

Gistituati, Nurhizrah, (2006), "Forum Pendidikan", Implementasi Program Perbaikan Mutu Sekolah: Beberapa Rekomendasi bagi Kepala Sekolah, 31, (1), 1-11.

Goleman, D., dkk (2004), Primal Leadership, Kepemimpinan berdasarkan Kecerdasan Emosi, Jakarta: PT. Gramedia Pustaka Umum.

Hersey, Paul dan Blanchard, Kenneth H. (1982), Management of Organizational Behavior, Utilizing Human Resources, Englewood Cliffs, New Jersey: Pretice Hall.

Hidayat, Dayat, (2004), "Wacana Kinerja", Jurnal Desentralisasi Bidang Pendidikan di Era Otonomi Daerah, 7, (2) 5762.

House, Robert J dan Mitchel, Terence R., (1974), "Path-Goal Theory of Leadership" Autumn: Journal of Contemporary Business, 81-97.

Hunger, David J. Dan Wheelen, Thomas L. (1996), Strategic Managemernt 5 th Edition, Florida: Published by Addison Wesley Publishing Company.

James Mac Gregor Burn, (1979), Leadership, New York: Happer Colophon Book-Happer \& Raw, Publishers.

Kartini, Kartono, (1998), Pemimpin dan Kepemimpinan, Jakarta: CV. Raja Grafindo Persada.

Keputusan Mendiknas RI, (2002), Pedoman Penyusunan Standar Pendidikan Dasar dan Menengah, Jakarta: CV. Sekala Jalmakarya.

Kusuma Seta, Ananto dan Wahab, Rochmat, (1998), Analisis Misi dan Visi Pembangunan Pendidikan dan Kebudayaan, Jakarta: Depdikbud-Biro Perencanaan, Sekretariat Jenderal.

Lembaga Administrasi Negara, (1992), Performance Improvement Planning, Suatu Pendekatan Perencanaan Peningkatan Kinerja (Prestasi Kerja), Jakarta: Pusat Kajian dan Diklat Aparatur I.

Lipham, James, M. (1985), The Principalship Concepts, Competencies, and Cases, USA: Longman New York.

Makmun, Abin Syamsuddin dan Satori, Djam'an, (1998), Analisis Posisi Pembangunan Pendidikan dan Kebudayaan, Jakarta: Depdikbud-Biro Perencanaan, Sekretariat Jenderal. 
Makmun, Abin Syamsuddin, (1996), Psikologi Kependidikan, Bandung: PT. Remaja Rosda Karya.

,(1996), Pengembangan Profesi dan Kinerja Tenaga Kependidikan, Bandung: Program Pasca Sarjana IKIP Bandung.

Maleong, Lexy J.,(2000), Metodologi Penelitian Kualitatif, Bandung: PT. Remaja Rosda Karya.

Mulyasa, E., (2002), Manajemen Berbasis Sekolah, Konsep, Strategi, dan Implementasi, Bandung: PT. Remaja Rosda Karya.

----------, (2002), Kurikulum Berbasis Kompetensi, Konsep, Karakteristik, dan Implementasi, Bandung: PT. Remaja Rosda Karya.

Nasution, S., (1996), Metode Penelitian Naturalistik-Kualitatif, Bandung: PT. Tarsito.

Patton, Patricia, (2002), EQ-Ketrampilan Kepemimpinan untuk melaksanakan tugas perubahan, Jakarta: CV. Mitra Media.

Peraturan Pemerintah RI Nomor 39, (2000), Peraturan Pemerintah tentang perubahan atas PP Nomor 38 tahun 1992 tentang Tenaga Kependidikan, Jakarta: CV. Novindo Pustaka Mandiri

Peraturan Pemerintah RI Nomor 19, (2005), Peraturan Pemerintah Republik Indonesia Nomor 19 tahun 2005 tentang Standar Nasional Pendidikan, Jakarta: CV. Eka Jaya.

Permadi, Dadi, (1999), Kepemimpinan Mandiri (Profesional) Kepala Sekolah, Bandung: PT. Sarana Panca Karya.

Poerwadarminta, W.J.S., (1986), Kamus Umum Bahasa Indonesia, Jakarta: PN. Balai Pustaka.

Prasetyo, Bambang dan Lina Miftahul Jannah, (2005), Metode Penelitian Kuantitatif, Teori dan Aplikasi, Jakarta: CV. Raja Grafindo Persada.

Rivai, Veithzal, ( 2004), Kiat Memimpin dalam Abad ke-21, Jakarta:CV. Raja Grafindo Persada.

Robbins, Stephen P., (2003), Perilaku Organisasi Jilid 2, Jakarta: PT. Gramedia.

Sallis, Edward, (1993), Total Quality Management in Education, London: British Library Cataloguing in Publication Data.

Satori, Djam'an, (2000), Peningkatan Mutu Pendidikan Berbasis Sekolah (Makalah), Bandung: Depdiknas. 
Satori, Djam'an, et-al., (2001), Pedoman Implementasi Manajemen Berbasis Sekolah di Jawa Barat-MBS Dewan Sekolah, Bandung: Dinas Pendidikan Propinsi Jawa Barat.

Satori, Djam'an, (2002), "Media Pendidikan" Jurnal Program Peningkatan Mutu Pendidikan Berbasis Sekolah (School Based Management), 1, (1), 1-7.

Sedarmayanti, (2004), "Wacana Kinerja", Jurnal Membangun Sistem Manajemen Kinerja Guna Meningkatkan Produktivitas Menuju Good Governance, 7, (2) 1-13.

Siagian, Sondang P. (2003), Manajemen Stratejik, Jakarta: PT. Bumi Aksara.

, (1982), Organisasi, Kepemimpinan, dan Perilaku Administrasi, Jakarta: PT. Gunung Agung.

----------, (1990), Teori dan Praktek Kepemimpinan, Jakarta: PT. Bina Aksara.

Soebagio Atmodiwirio dan Soeranto Totosiswanto, (1991), Kepemimpinan Kepala Sekolah, Semarang: CV. Adhi Waskita

Sudjana, (1996), Metode Statistika, Bandung: PT. Tarsito.

Sudjana, H.D, (2000), Manajemen Program Pendidikan, Bandung: Falah Production

Sugiyono, (1999), Metode Penelitian Administrasi, Bandung: CV. Alfabeta

Supriadi, Dedi, (2000), Jaring Pengaman Sosial Pendidikan, Bandung: CV. Alfabeta.

---------, (1998), Mengangkat Citra dan Martabat Guru, Yogyakarta: CV. Adicita Karya Nusa.

---------, (2004), Membangun Bangsa melalui Pendidikan, Bandung: PT. Remaja Rosda Karya.

Surakhmad, Winarno, (2004), Pengantar Penelitian Ilmiah, Dasar, Metode, dan Teknik, Bandung: PT. Tarsito.

Thoha, Miftah, (1999), Perilaku Organisasi, Jakarta: CV. Raja Grafindo Persada.

----------, (1999), Kepemimpinan dalam Manajemen, Jakarta: CV. Raja Grafindo Persada.

Thomas, J. Sergiovanni, (2002), Moral Leadership, San Francisco: Jose Bas Publiser.

Tim Dosen Administrasi Pendidikan, (2003), Pengantar Pengelolaan Pendidikan, Bandung: Jurusan Administrasi Pendidikan FIP UPI. 
Tim Kelompok Kerja MBS Jawa Barat, (2003), Implementasi Manajemen Berbasis Sekolah di Jawa Barat, Bandung: Dinas Pendidikan Propinsi Jawa barat.

Tjiptono, Fandy \& Diana, Anastasia, (2003), Total Quality Management, Yogyakarta: CV. Andi.

Tafsir, Ahmad, (2005), Ilmu Pendidikan dalam Perspektif Islam, Bandung: PT. Remaja Rosda Karya.

Undang Undang RI Nomor 20, (2003), Sistem Pendidikan Nasional, Jakarta: Dirjen Dikdasmen.

Undang-Undang RI Nomor 32, (2004), Sistem Pemerintahan Dearah, Jakarta: CV. Eka Jaya.

Undang Undang RI Nomor 14, (2005), Guru dan Dosen, Jakarta: CV. Eka Jaya.

Wahjosumidjo, (1999), Kepemimpinan Kepala Sekolah, Jakarta: CV. Raja Grafindo Persada. 